\title{
Benchmarking evaluation of contractors' maturity in the implementation of social responsibility based on the management process of stakeholder
}

\author{
${ }^{1, a}$ lore wenhui liang 2,b JiaWei Xue \\ 1,2, Construction and management Department, Tsinghua University, BeiJing 610084, China \\ a,b,wenhuiliang@hotmail.com
}

Keywords: Stakeholder theory; contractor; social responsibility; maturity; benchmarking evaluation.

\begin{abstract}
Corporate social responsibility has been considered as an indispensable basis for competitiveness under the trend of globalization. Although the performance management and evaluation of social responsibility and improvement direction of enterprise development, but due to the different environmental background, the definition of corporate social responsibility are slightly different, therefore, the simple evaluation of its performance will be very difficult. Even though various researches intend to summarize the evaluation framework for construction social responsibility, but due to the difficulties of data collection and too many evaluation indicators, the evaluation framework still cannot be compatible with the corporate management in reality. This paper is based on identifying how construction corporate performs CSR, so as to summarize the developing principle of construction corporate; it performs the Organizational Project Management Maturity Model (hereinafter referred to as "OPM3 Model") to propose the Construction Management Maturity Model of Corporate Social Responsibility. The contribution of this study is establishing the Contractors' Corporate Social Responsibility (CCSR) model based on the original OPM3 model.
\end{abstract}

\section{Introduction}

Corporate social responsibility (CSR) means an enterprise's responsibility for its shareholders, employees, consumers, society and environment while creating profits. [1] Adam Smith, "the Father of Economics", once said if the social wealth failed to be shared by the whole society, the society would not be stable, and thus, we can see how important for an enterprise to shoulder responsibility. [2-3] The importance of corporate social responsibility is demonstrated in the following two aspects: its own development and the harmony of society. For the enterprise itself, it is a must to achieve the long-term development, on one hand, if the enterprise takes the initiative on taking the social responsibility, it can attract employees to stay and has more excellent talents for its development; on the other hand, it can raise its market competitive power through the reduction of its operational cost achieved by cutting down on the energy consumption and other investment during its operation. However, the research and investigation indicate many a construction enterprise sees an unsustainable development due to the lack of competitiveness resulted from social responsibility.

\section{Evaluation model of corporate social responsibility}

Normally, the evaluation of social responsibility is conducted through questionnaire or interview, and then, researchers wish to minimize the social desirability bias effect (SDB) [4], this is because that respondents tend to show their bests intentionally or unconsciously when filling in the questionnaires, however, the answers of these topics are usually sensitive, for example, information of security, and thus, the questions designed for the questionnaires should be of no conflict, but can collect necessary information. The principles of designing the questions consist of: 1.the behavior or attitude described in the question should be neither too penetrating nor too sensitive; 2.esnure the confidentiality in the way of self-evaluation 3 . When conducting the description of the behavior or attitude that is hard to be accepted by the society, you should explain the reason so as to prevent over-reporting; when 
conducting the opposite one, you should make positive confirmation to avoid under-reporting (CM: new direction p.179-182), in June, 1971, Committee for Economic Development issued Corporate Social Responsibility (Commercial Law), expounding the focus of this report is on the part of non-economic content in the corporate social responsibility and listing up to 58 suggestions of action facilitating the social progress, which cover the following 10 aspects:1.economic growth and efficiency;2. education;3.employment and training;4. civil rights and equal opportunity ; 5. urban reconstruction and development;6. preventing and combating pollution; 7. protection and regeneration of (resources);8.culture and art; 9. medical service ;10. government[5-7]. From then on, international organizations and authoritative organizations also one after another have issued standard systems, conventions and the indexes of evaluation, etc. related to the implementation of social responsibility. of them, Social Accountability 8000 (SA8000), the globally first international standard for qualifying the social responsibility of the third party, is raised by Social Accountability International (SAI), an organization affiliated to the non-governmental organization Council on Economic Priorities and is widely applicable for the moment. In addition, ISO 26000 in question is the lately-issued guidance of social responsibility standard by ISO in 2010 and also, is by now the most comprehensive and authoritative social responsibility system with 7 major categories of topics covering 200 indexes, which is more that of SA8000.meanwhile, various institutions have one after another issued corresponding documents of standardization system on the relevant topics related to social responsibility, for example, ISO 8000 quality management system, ISO 14000 quality management system, OHSAS18000 evaluation system of standardization for occupational health and safety, et al. As each standard and index document in question are compatible with ISO 26000, so they can play the supplementary and deepening role [9]. But these systems of standardization focus on defining the concept and scope of corporate social responsibility, and further discussion about the approach and form of evaluation should be taken into accounting when conducting it.

For the establishment of index, Dow Jones index for sustainable development is the first index system worldwide that introduces the concept "sustainable development" and is demonstrated by corporate financial index. At present, the relatively universal indexes of evaluation are Domini and Ethible sustainable development. For the moment, the relatively general indexes are mainly about corporate financial indexes, focusing on whether the implementation of social responsibility can create long-term economic benefits rather than the implementation itself of CSR, so they have a limited enhancement in the capacity for implementing CSR internally and systematically. [10-12]In the perspective of benchmark, Zhao et al constructed benchmarking frame of CSR for contractors in 2012, which consist of indexes at three levels, the first layer is comprised of different stakeholders of 9 categories, the second includes 30 indexes of grade II under each stakeholder and the third is about the subdivision of the indexes in the second layers [13]. Although this system is still complete and perfect, too many layers and indexes will pose a bad maneuverability when establishing index weight and implementing evaluation. In 2012, Li jun made an analysis of Mengniu's implementation of corporate social responsibility and qualitative analyses focused on its employees, consumers, stakeholders and external environment of society, which did not involve concrete index of quantization.

Generally speaking, most evaluations of CSR's performance still take financial performance as reference. Although these indexes look reasonable, but two high cost of collection makes it a low feasibility.

\section{Benchmarking evaluation model based on the management process of stakeholder}

In the process of project management, the stakeholder of the project has an important or even leading role in the process of the project's development and implementation. To correctly identify the stakeholders and establish relations with them play a decisive role in the project's success. Maturity means achieving the desirable quality or status, OPM3 thinks the extent that an organization meet 
some best practice can be used to describe the maturity of project management, and capacity for management, to some extent, serves as the precondition the ensure the organization to attain best practice. Management model for contractor's implementation of CSR serves as the guidance of model for construction enterprise contractor to implement its CSR so as to strengthen the management of CSR of construction enterprise [14].

\section{Evaluation model}

The existing research indicates that corporate behavior responds to the maturity of CSR and the evaluation of cost should be completed by employing best practice and corporate manifest capacity to estimate its maturity of CSR. And therefore, this research, in accordance with the basic contents of CSR, uses the core thought and multi-dimensional elevation form of OPM3 and arises the evaluation model of Contractors' Corporate Social Responsibility (CCSR), which consists of three basic dimensions [16] :

\section{(1) Connotation of CSR}

This dimension serves as the concrete content to investigate the maturity. We, on the basis of the theory of stakeholder, collect management practice of renowned contractors' management practice, and classify them as per the definition of maturity.

Table 1 CCSR KPI-BP-Capability relations

\begin{tabular}{|c|c|c|c|c|c|c|c|c|}
\hline \multirow{2}{*}{ Key Issue } & \multirow{2}{*}{ Best Practice } & \multicolumn{3}{|c|}{$\begin{array}{l}\text { management scope of } \\
\text { CSR }\end{array}$} & \multicolumn{4}{|c|}{ Maturity } \\
\hline & & Project & $\begin{array}{l}\text { Are } \\
\text { a }\end{array}$ & $\begin{array}{l}\text { Headqu } \\
\text { arters }\end{array}$ & $\begin{array}{l}\text { Emerg } \\
\text { ence }\end{array}$ & $\begin{array}{l}\text { Develo } \\
\text { pment }\end{array}$ & $\begin{array}{l}\text { Perfect } \\
\text { ion }\end{array}$ & $\begin{array}{l}\text { Integra } \\
\text { tion }\end{array}$ \\
\hline $\begin{array}{l}\text { offer fair } \\
\text { opportunity }\end{array}$ & $\begin{array}{l}\text { Open } \\
\text { recruitment }\end{array}$ & $\sqrt{ }$ & $\sqrt{ }$ & $\sqrt{ }$ & $\sqrt{ }$ & & & \\
\hline & Fair recruitment & $\sqrt{ }$ & $\sqrt{ }$ & $\sqrt{ }$ & & $\sqrt{ }$ & & \\
\hline $\begin{array}{l}\text { employme } \\
\text { nt and } \\
\text { formal }\end{array}$ & $\begin{array}{l}\text { Discrimination } \\
\text { prohibited }\end{array}$ & & & $\sqrt{ }$ & & & $\sqrt{ }$ & \\
\hline $\begin{array}{l}\text { employme } \\
\text { nt } \\
\text { relationshi } \\
\text { p }\end{array}$ & $\begin{array}{l}\text { Diversified } \\
\text { options }\end{array}$ & & & $\sqrt{ }$ & & & & $\sqrt{ }$ \\
\hline
\end{tabular}

In each management practice, we need to further define the capacity that meet the requirement of corresponding management practice as the basis of evaluation. The description of capacity should be done as detailed as possible so as to avoid the ambiguity during enterprise's self-evaluation. For instance, it is prohibited to set up discriminative clauses for the item of "open recruitment" under Best Practice in the information of recruitment and it calls for two capacities before meeting the Best Practice, namely, "enterprises announce the plan of open recruitment to the public and the personnel within the enterprise" and "the information of recruitment does not include the restrictive conditions against the provisions of the relevant laws and regulations issued by the state such as sex, registered permanent residence, educational background and college or university of graduation". When the enterprise meet the two requirements, it has the prerequisite for implementing the item of "open recruitment and no discriminative clauses in the information of recruitment" under the Best Practice. [17]

(2) Levels of CSR management

For general contractor of large project, its organizational structure is normally based on the three levels of headquarters, region and project. The first level, namely, headquarters are responsible for formulating strategy and institution, the second for the distribution of resources and the last for the actual operation. 
(3) The maturity of CSR's Implementation-emergence, development, perfection and integration Maturity of CSR, in accordance with CSR's four strategic phases (strategy of disobedience, strategy of passive obedience, strategy of adaptation and win-win strategy) and its law of development, can be divided into four extents, namely, emergence, development, perfection and integration, each of which responds to the each phase in question. [18]And therefore, we can approximately judge the phase implemented by the enterprise by identifying the maturity of organization.

104 items of Best Practice(26 key issues and each issue include four items of Best Practice) is summerized in this research. As CSR's managment scope over some items under Best Practice is not signel, for example, the managment scope over the item of "open recruitment and no discriminative clauses in the information of recruitment" under the Best Practice covers the three items of "project", "region" and "headquarters". And therefore, when collecting the number of Best Practice in the maturity and CSR's management scope (see Table 2), we find, according to the statistics, the total is over the actual number of Best Practice.

Table 2 Colleciton of the number of Best Practice in the maturity and CSR's management scope

\begin{tabular}{llllll}
\hline & Emergence & $\begin{array}{l}\text { Developme } \\
\mathrm{nt}\end{array}$ & Perfection & Integration & Total \\
\hline Project & 14 & 10 & 5 & 5 & 34 \\
Region & 9 & 12 & 13 & 8 & 42 \\
Headquarters & 11 & 11 & 15 & 20 & 57 \\
Total & 34 & 33 & 33 & 33 & 133 \\
\hline
\end{tabular}

As Table 2 shows, with the raising of maturity, the number of Best Practice at the level of project reduces gradually while at the headquarters, with the raising of maturity, the number grows gradually. At the level of region, the quantity of Best Practice at the phases of "development" and "perfection" is relatively larger, which indicates that the focus of CSR's management has been, step and step, transferred to region and to the headquarters in the end with the enhancement in the maturity of CSR. The number of Best Practice in the topic and CSR's management scope is summarized as the Table 3. Table 3 Colleciton of the number of Best Practice in the topic and CSR's management scope

\begin{tabular}{|c|c|c|c|c|c|c|c|c|}
\hline & $\begin{array}{l}\text { Practice } \\
\text { of labor }\end{array}$ & $\begin{array}{l}\text { Enviro } \\
\text { nment }\end{array}$ & $\begin{array}{l}\text { Practice } \\
\text { of fair } \\
\text { operati } \\
\text { on }\end{array}$ & $\begin{array}{l}\text { Communit } \\
\text { y's } \\
\text { participati } \\
\text { on and } \\
\text { developme } \\
\text { nt }\end{array}$ & $\begin{array}{l}\text { Hum } \\
\text { an } \\
\text { right } \\
\text { s }\end{array}$ & $\begin{array}{l}\text { Rights of } \\
\text { stakehold } \\
\text { er }\end{array}$ & $\begin{array}{l}\text { Manage } \\
\text { ment of } \\
\text { organizat } \\
\text { ion }\end{array}$ & Total \\
\hline Project & 10 & 7 & 7 & 5 & 5 & 0 & 0 & 34 \\
\hline Region & 9 & 4 & 14 & 11 & 4 & 0 & 0 & 42 \\
\hline $\begin{array}{l}\text { Headquarter } \\
\mathrm{s}\end{array}$ & 20 & 7 & 8 & 5 & 5 & 4 & 8 & 57 \\
\hline Total & 39 & 18 & 29 & 21 & 14 & 4 & 8 & 133 \\
\hline
\end{tabular}

Of them, the major management scopes of such topics as "Practice of Labor, Environment and Management of Organization" focus on the level of "headquarters" while the management of such topics as "Practice of fair operation and Community's participation and development" is dominated by "Region". The topics of "Human rights and Environment" are under the joint management of project, region and headquarters.

Approach of testing:OPM3 thinks that the result of the implementation of practice indicates whether the enterprises have the corresponding capacity for management. From the angle of management, a certain capacity of management serves as the preconditions of the implication of Best Practice, and which is also a good approach of evaluating the internal features, [19] and therefore, CCSR judge whether an enterprise meets the requirements of the implementation of Best Practice by testing 
whether the enterprise has some capacities of management or not. Approvers can further determine the maturity of implementation for CSR of some KPI by synthesizing the descriptions of maturity responds to various items of Best practice. We combine all the results of evaluation for KPI..

On the basis of identifying the maturity, we need to identify the capacity of practice under each maturity and take it as the standard to judge whether it meets the recruitments of this maturity. Each Best Practice may include several capacities, and we can judge it reaches the corresponding maturity of Best Practice as long as it meets all the requirements of capacities.

The Maturity of CSR:For the impetus that an enterprise implements CSR, it has witnessed the change from "external pressure" to "enterprise's own internal values", which can be used to describe the maturity of CSR's implementation.

\section{(1) Emergence}

At this phase, contractor of project takes "disobedience" as its major principle to formulate its own strategy. The typical management behaviors of enterprise at this phase consist of: strengthen the communications of organization with the society, pay close attention to the activities of public welfare launched in the seat of enterprise' seat, invest some funds in charity (for example, offer scholarship), etc, which are aimed at enhancing corporate reputation in the society and create a good social environment of public opinion so the protect can proceed smoothly. Enterprise, for its survival in the market, is forced to implement its CSR. At this phase, enterprise's professional service of project is not greatly related to its behaviors of implementing the CSR and has relatively high randomness, or take CSR as the guidance of its development or combine CSR with concrete behavior of management.

(2) Development

With the spreading of such concepts as sustainable development and operation and the implementation of CSR within the project contractors, they realize the important of CSR for corporate development and the concept of CSR has been demonstrated in their own behaviors of management step by step. Enterprise no longer, merely due to the pressure from the society, conducts the behaviors that have no bearing on its project, aiming at forming its own competitiveness and brand premium of CSR. At this phase, enterprise will pay more attention to enhancing its own management capacity of CSR and emphasize the sustainability of the product and service of project, whose typical behaviors include carrying out sustainable construction and operation, focusing on green architecture, adopting the life circle evaluation of construction project, keeping perfecting the management system of occupational health and safety, etc. As the impetus for implementing CSR is more voluntary than that at last phase, enterprise will be relatively active to do it. However, the behaviors conducted at this phase are still confined to the change of management system and they don't take workable measures in the project

(3) Perfection(maturity)

At this phase, enterprise regards CSR as the core of its competitive power, stressing that project contractor achieve real operation of localization in its business and take the initiative on implementing the behaviors that are in line with the mind of CSR. At this phase, enterprise seeks to take the lead within the industry and affect the industry. Typical behaviors include: the green architecture standard, which has an impact on the industry and ensure the occupational health and safety of employees through influencing the regulations of the industry; advocating fair competition between enterprises, resist behaviors of industrial corruption and actively take part in the construction of community and the improvement in its welfare. Although, at this phase, enterprise has an impact on the locality or even on the standards and regulations of the industry, it emphasizes the influencing power of its own, but pays little attention to the stakeholders of project.

(4) Integrity (win-win) 
The impetus for enterprise's behaviors to implement CSR is stemmed form its interior and the goal it strives for is to make itself and parties concerned get what they want, achieving "win-win". At this phase, enterprise has integrate the mind of CSR into its own daily management strategy as a routine and behaviors of CSR are no longer temporary actions to manage project and take the demands of several stakeholders into account. The typical behaviors are comprised of professional service of project and the activities of social charity, for example, take some professional service of project to offer service of education to the vulnerable group in the society.

\section{Conclusions}

In this research, we establish the evaluation model of CCSR in accordance with the basic contents of CSR, uses the core thought and multi-dimensional elevation form of OPM3 . we assume that CCSR evaluation model increase the efficiency of identifying how enterprise perform Corporate social responsibility. In the further research, we hope to apply our CCSR model to the construction corporate cases to validate this model.

\section{References}

Pang Yongshi, Wang ying. The determination of evaluation index and weigh based on the rough set of corporate social responsibility [J]. Journal of Industrial Engineering and Engineering Management, 2012 (3):109-113

Zhu Yongming. Research on maturity of the implementation of corporate social responsibility [J]. Journal of Zhengzhou University (Philosophy and Social Sciences Edition ), 2009(6):90-93

Pan Jiren, Lin Zhiyan, Jia Guangshe. Research on the maturity management of project for construction enterprise. Journal of Civil Engineering, 2009,12:183-188

Ced. Social Responsibilities of Business Corporations [EB/OL]. [2014-03-01]. http://www.ced.org/reports/single/social responsibilities of business corporations.

Ohsas. OHSAS 18000 Occupational health and safety management systems[S]. 2007.

Ungc. United Nations Global Compact[S]. UN, 2000.

Zhao Z, Zhao X, Davidson K, et al. A corporate social responsibility indicator system for construction enterprises. Journal of Cleaner Production, 2012, 29:277-289.

Pmi. Organizational Project Management Maturity Model (OPM3) [EB/OL]. [2014-03-01]. https://www.pmi.org/en/Business-Solutions/Organizational Project Management.aspx.

Iso. ISO 26000 Guidance on Social Responsibility[S]. 2010.

Pmbok. Guide to the project Management body of knowledge. Project Management Institute, Pennsylvania USA, 2000.

Curtis D B, Hefley W E, Miller S A. The people capability maturity model: Guidelines for improving the workforce. Addison-Wesley, 2002.

Lou Rundong. Political economy [M]. Beijing : Tsinghua university press, 2010.

Han Qingxiang. Management of corporate behavior [M]. Beijing: China Economy Press, 2001.

Paulk M. Capability maturity model for software. Wiley Online Library, 1993.

Pan Jiren, Lin Zhiyan, Jia Guangshe. Research on the maturity management of project for construction enterprise [J]. Journal of Civil Engineering, 2009,12:183-188.

De Bruin T, Rosemann M. Towards a business process management maturity model. 2005.

Paulzen O, Doumi M, Perc P, et al. A maturity model for quality improvement in knowledge management. 2002.

Fisher D M. The business process maturity model: a practical approach for identifying opportunities for optimization. Business Process Trends, 2004, 9(4):13. 
Kerzner H R. Strategic planning for project management using a project management maturity model. John Wiley \& Sons, 2002. 